84 J.H. Murib, U.S. Pat. 4,107,204 (1978)

85 G. Scharfe, J. Grolig, M. Martin, W. Swodenk and W. Dornfeldt, Ger. Offen. $1959780(1971)$

86 D. Freudenberger, F. Wunder and H. Fernholz, Ger. Offen. 2553761 (1977)

87 D. Freudenberger and F. Wunder, Ger. Offen. 2715667 (1978)

88 J. Petro, T. Mathe, S. Szoke, G. Lugosi and L. Feuer, Fr. Demande 2,232,539 (1975)

89 I. A. Zubovitch, Zbur. Fiz. Kbim, 1955, 29, 1696-1705

90 I.A. Zubovitch, Zhur Fiz Khim 1957, 31, 589-508

91 J.A. Scheben and I.L. Mador, in '5th Conf. Catal. Org. Synth.', 1975, pp. 181-201 edited by P.N. Rylander and H. Greenfield, Academic Press, New York, 1976

92 R.F. Vines, 'The Platinum Metals and their Alloys', The International Nickel Company, Inc., New York, 1941

93 M. Hansen and K. Anderko, 'Constitution of Binary Alloys', 2nd ed., McGraw Hill, New York, 1958

94 J.K.A. Clarke, I. Manninger and T. Baird, J. Catal., 1978, 54, $230 \cdot 242$

95 F.J. Kuijers, R.P. Dessing and W.M.H. Sachtler, J. Catal, 1974, 33, 316-321

96 H.C. DeJongste, F.J. Kuijers and V. Ponec, in 'Preparation of Catalysts', edited by B. Delmon, P.A. Jacobs and G. Poncelet, Elsevier, Amsterdam/New York, 1976 , p. 207

97 S.M. Kulifay, J. Amer. Cbem. Soc, 1961, 82, 4916

98 R.S. Miner,Jr., S. Namba and J. 'Turkevich, Stud. Surf. Sci. Catal, 1981, 7, (PL.A. New Horiz Catal ) 160.172

99 J. Turkevich, R.S. Miner, Jr., I. Okura, S. Namba and N. Zacharina, in 'Perspect. Catal., (Proc. 12th Swed. Symp. Catal.)', 1979 (Pub. 1981), pp. 111-122

100 S. Galvagno and G. Parravano, J. Catal., 1979, 57, 272-286

101 P.R. Norton, R.L. Tapping and J.W. Goodale, J. Vac. Sci. Technol., 1977, 14, 446-451

102 K.M. Sancier and S.H. Inami, J. Catal., 1968, 11, 135

103 J.A. Schwarz, R.S. Polizotti and J.J. Burton, J. Vac. Sci. Technol., 1977, 14, 457

104 D.S. Wang, A.J. Freeman and H. Krakauer, Phys. Rev. B: Condens. Matter, 1984, $29,1665-1673$

105 P. Biloen, R. Bouwman, R.A. VanSanten and H.H. Brongersma, in 'Proceedings 7th International Vacuun Congress, and 3rd International Conference on Solid Surfaces', edited by Dobrozemsky et al. Vienna 1977, Vol, 2, p. 1401

106 J.R. Anderson, K. Foger and R.J. Breakspere, I. Catal., 1979, 57, 458-475

107 J.R. Anderson and R.J. Breakspere, in 'Proceedings 7 th International Vacuum Congress, and 3rd International Conference on Solid Surfaces', edited by Dobrozemsky et al, Vienna 1977, Vol. 1, pp. 823-826

108 R. Bouwman and W.M.H. Sachtler, J. Catal., 1970, 19, 127-140
109 D.W. Budworth, F.E. Hoare and J. Preston, Proc. Roy, Soc, 1960, 257, 250

110 A.S. Darling, P.A. Mintern and J.C. Chaston, J. Inst. Met., 1952, 81, 125

111 G.H. Johansson and I.O. Linde,Ann. Phys., 1930, 5, 762

112 J.J. Stephan, V. Ponec and W.M.H. Sachtler, Surface Sci., 1975, 47, 403

113 K. Foger and J.R. Anderson, Appl. Surf. Sci, 1979, 2, 335-351

114 H.C. Dejongste and V. Ponec, J. Catal., 1980, 64, 228-231

115 J.J. Stephan and V. Ponec, J. Catal., 1976, 42, 1-9

116 R.P. Dessing and V. Ponec, J. Catal., 1976, 44, 494-497

117 JW. A Sachtler, Preprints, A.C.S. Div Petrol Chem. 1983, 28, $491-503$

118 J.R.H. van Schaik, R.P. Dessing and V. Ponec, J. Catal., 1975, 38, 273-282

119 J.K.A. Clarke, A.F. Kane and T. Baird, J. Catal., 1980, 64, 200-212

120 R.P. Dessing and V. Ponec, Reaction Kinet, Catal. Lett., 1976, 5, 251

121 K. Foger and J.R. Anderson, J. Catal., 1980, 61, 140-145

122 R.P. Dessing, V. Ponec and W.M.H. Sachtler, J. Chem. Soc, Chem. Commun. $1972,(15), 880-881$

123 D.I. Hagen and G.A. Somorjai, J. Catal., 1976, 41, 466-481

124 J.W.A. Sachtler, M.A. Van Hove, J.P. Bibérian and G.A. Somorjai, Pbys, Rev Lett, $1980,45,1601-1603$

125 A.A. Alchudzan and M.A. Indzhikyan, Zhur Fiz. Khim 1959, 33, 983-987

126 P. Biloen, F.M. Dautzenberg and W.M.H. Sachtler, J. Catal., 1977, 50, 77-86

127 S. Galvagno and G. Parravano, Ber. Bunsenges. Phys. Chem., 1979, 83, 894-899

128 L. Guczi, J. Molec, Catal., 1984, 25, 13-29

129 A. Van der Burg, J. Doornbos, N.J. Kos, W.J. Ultee and V. Ponec, J. Catal. $1978,54,243-253$

130 A.A. Rudnitskii and O.A. Novikova, Russ. J. Inorg. Chem., 1959, 4, 722

131 J. Schwank, G. Parravano and H.L. Gruber, J. Catal., 1980, 61, 19-28

132 S. Galvagno, J. Schwank and G. Parravano, ]. Catal. 1980, 61, 223-231

133 I.W. Bassi, F. Garbassi, G. Vlaic, A. Marzi, G.R. Tauszik, G. Cocco, S. Galvagno and G. Parravano, J. Catal., 1980, 64, 405-416

134 G.R. Tauszik, F. Garbassi and A. Marzi, Gazz. Chim. Ital., 1980, 110, 443-448

135 S. Galyagno, J. Schwank. G. Parravano, F. Garbassi, A. Marziand G.R. Tauszik, J. Catal., 1981, 69, 283-291

136 G. Leofanti, M. Solari, G.R. Tauszik, F. Garbassi, S. Galvagno and J. Schwank, Appl. Catal. 1982, 3, 131-139

137 G.R. Tauszik, G. Leofanti and S. Galvagno, J. Molec. Catal, 1984, 25, 357-366

138 A.K. Datye and J. Schwank, in 'Proc. 8th Inter. Congress on Catalysis', Berlin (West), Vol. 4, pp 587-598, Verlag Chemie Weinheim, West Germany, 1984 139 A.K. Datye, Ph.D. Thesis, The University of Michigan, 1984

140 J.W.A. Sachtler and G.A. Somorjai, J. Catal., 1983, 81, 77-94

141 J.W.A. Sachtler and G.A. Somorjai, J. Catal., 1984, 89, 35-43

\title{
Enhanced Bonding of Gold Films by Ion-Assisted Deposition
}

One of the basic criteria to be satisfied in thin-film technology is strong adherence of the film to the substrate. Many applications of thin gold films on different substrates are to be found in this technology, and the achievement of good reproducible adhesion between gold and the substrate, in particular glass, still presents a problem on which much work is still being done. One method which has frequently been used to improve the adhesion of films is that of oxygen glow-discharge cleaning of the substrates before the deposition of gold. However the role of oxygen in the process has not been satisfactorily explained, and variable results are often obtained.

Recent work on the development of the technique of ion-assisted film deposition by P.J. Martin, W.G. Sainty, R.P. Netterfield and their co-workers at the Division of Applied Physics, CSIRO, Australia (J. Appl. Phys., 1984, 55, 235 and Appl. Opt., 1983, 22, 178) has enabled thin film properties, particularly refractive index and density, to be modified substantially. In addition, Martin, Sainty and Netterfield have reported (Appl. Opt., 1984, 23, (16), 2668-2669) on their experiments in which thin films of gold on polished glass substrates were deposited by ion-assisted electron beam evaporation, and the adhesion of the films examined.

In this work the films ( $\sim 100 \mathrm{~nm}$ thickness) were deposited (a) without ion assistance, (b) under argon-ion bombardment, and (c) using oxygen-ion bombardment. Gold film adhesion was measured by scratch testing using a diamond stylus with a radius of either 65 or 250 micrometres with fil $\mathrm{m}$ failure being defined as partial or total removal from the $15 \mathrm{~mm}$ scratch track.

The results of this work clearly showed that oxygen-ion assisted gold deposition yielded films with adhesion levels markedly above those formed by normal electron beam evaporation - one to two orders of magnitude improvement are quoted in this work. One undesirable feature of oxygen-ion assisted gold film deposition is the characteristic brown colour of the film leading to some reduction in the film reflectance. The authors have overcome this problem by switching off the oxygen-ion beam once a continuous film has been formed, and continuing gold evaporation to final film thickness. By this means high adhesion without loss in reflectance is achieved.

Argon-ion assisted gold deposition shows little or no improvement in film adhesion and the authors suggest that the mechanism by which adhesion is increased with the use of oxygenion assistance involves the formation of a stable compound at the point of film formation which bonds the gold film to the substrate. The brown colouration of the gold film may also, of course, suggest some formation of gold oxide.

The success of this work is a welcome addition to the literature describing the ongoing effort to improye the adhesion of gold films for use in thin film technology.
C.I. 